I Universidade de São Paulo (USP), Departamento de Ciência

Política, São Paulo, SP, Brasil

belinelli.leonardo@gmail.com

https://orcid.org/oooo-0002-4622-5366

Leonardo Octavio Belinelli de Brito'

\title{
REPÚBLICA, DEMOCRACIA E CIDADANIA EM TEMPOS DE PANDEMIA: UMA NOTA SOBRE A SITUAÇÃO BRASILEIRA
}

Como ocorre em tempos de crises profundas, a disseminação do novo coronavírus pelo mundo tem colocado em xeque alguns dos pilares das ordens política, social e econômica vigentes. Por consequência, novas questões surgem, enquanto antigas ressoam em novo timbre. Muitos cientistas - das ciências biológicas e das ciências humanas - têm se destacado ao formulá-las, interpretá-las e/ou esclarecê-las na esfera pública, com grande repercussão. Para ficar em um exemplo, a recente participação do microbiologista Atila Iamarino bateu um recorde de audiência no tradicional programa Roda-Viva da TV Cultura.

No caso das ciências sociais, ${ }^{\mathrm{I}}$ sua capacidade de interpelar o momento crítico em que vivemos tem a ver com o fato de que as dinâmicas, críticas ou não, das diversas sociedades sobre as quais se debruçam moldam seus principais objetos de estudo. Entre os diversos exemplos possíveis, é suficiente recordar o papel que processos revolucionários dos séculos XVII, XVIII e XIX tiveram na conformação do vocabulário da teoria e da prática política. Indo mais longe na vinculação entre ciências sociais e os problemas relacionados aos momentos críticos, podemos, com Florestan Fernandes (I97 I: 67), lembrar que a própria "sociologia emergiu em um momento crítico da civilização ocidental". É a partir desse ângulo que, a seguir, procuro chamar a atenção para alguns aspectos sociais e políticos da pandemia que nos cerca.

Entre as principais questões suscitadas pela pandemia da covid-19, particularmente em nações periféricas como o Brasil, está o seu impacto desigual 
em sociedades marcadamente estratificadas. Ou seja, há uma dimensão propriamente social no problema do combate à pandemia, que é dificultada pela própria forma da sociedade em que ocorre. Uma das suas facetas, por exemplo, é a falta de condições materiais de parcela significativa da população brasileira para exercer as recomendações das autoridades médicas e sanitárias. A vulnerabilidade se estende ao problema da cobertura efetiva da saúde pública. A sua principal ferramenta, o Sistema Único de Saúde (SUS), uma conquista decisiva na cidadania brasileira do período sob a Constituição de I988, tem sofrido historicamente com falta de financiamento (Périssé, 2020).

A combinação entre as ameaças à vida trazidas pelo coronavírus e a forte desigualdade material coloca em forte tensão o pressuposto igualitário da cidadania vigente no país, especificado no artigo quinto da Constituição de I988, no qual lemos: “Todos são iguais perante a lei, sem distinção de qualquer natureza, garantindo-se aos brasileiros e aos estrangeiros residentes no País a inviolabilidade do direito à vida, à liberdade, à igualdade, à segurança e à propriedade" (o grifo é nosso). Esse é um dos pilares da República (art. Iº, inciso II) e embasa um de seus objetivos, "construir uma sociedade livre, justa e solidária" (art. $3^{\circ}$, inciso I). É claro que a lei, em si mesma, nada pode fazer para combater o risco. Pode - e deve, em um regime verdadeiramente republicano -, porém, guiar governantes e governados sobre as prioridades que devem ser estabelecidas.

Dito isso, é preciso recordar duas das principais advertências dos clássicos do nosso pensamento social e político: que entre a letra da lei e a realidade social, há uma vasta distância; que tal descompasso e o seu sentido mudam segundo o lugar social ocupado pelos cidadãos envolvidos. Ora, ambas problematizam ideias que estão no âmago das noções de república e democracia. O ideal da primeira é o "governo da lei", ou seja, que os cidadãos sejam governados por normas não arbitrárias e com aplicação indistinta; já a segunda preconiza a maior incorporação possível dos sujeitos à condição de cidadania (Schwarcz, Starling, 20I9). Portanto, se a lei não vale de modo igualitário, não temos uma república; e se não há uma efetiva incorporação de todos à condição cidadã, não existe democracia. Por essa razão a procura de compreender como tais dissonâncias se produziram e seus efeitos se tornaram verdadeiras obsessões das ciências sociais brasileiras (Botelho, Ricupero, Brasil Jr., 20I7), frequentemente informadas por hipóteses, argumentos e perspectivas formulados pelos “intérpretes do Brasil” (Brandão, 2007).

Um dos principais intérpretes do percurso da cidadania no país, o historiador e cientista político José Murilo de Carvalho (2016), indica que um dos resultados dessa evolução contraditória dos direitos no país, ao menos em matéria dos relacionados aos assuntos civis, foi o estabelecimento de três "classes" de cidadão: "os doutores", os "cidadãos simples" e os "elementos". Os primeiros se encontram "acima da lei"; os segundos têm seus direitos respeitados de 
maneira incerta, e aos terceiros caberia "apenas o Código Penal”. Não extrapolaríamos o raciocínio do autor ao indicar que os cidadãos brasileiros possuem em baixa conta as instituições que são, precisamente, os instrumentos de que deveriam dispor para efetivar sua condição cidadã. Por isso, uma resposta adequada das instituições, nesse contexto pandêmico em que vivemos, é vital para alterar o quadro.

Diante da potência do consórcio entre crise econômica mundial e política nacional, a proposição anterior pode parecer ingênua. Afinal de contas, como uma cidadania frágil poderia conter uma avalancha como essa? Nesse cenário, não seria muito mais provável um agravamento dos desequilíbrios da sociedade brasileira? Analistas, nacionais e estrangeiros, têm se dividido sobre o assunto. Parece ser mais prudente a postura que reconhece as possibilidades de uma tragédia social e, ao mesmo tempo, recorda que sua magnitude não está dada, pois está em disputa, nem impede que se abram possibilidades renovadoras. São elas que, se aprofundadas, podem nos recuperar da crise da saúde, da crise econômica e também da crise cidadã que vivemos.

$O$ atual quadro, grave, permite vislumbrar três indícios que podem anunciar um novo momento. São eles: a importância do SUS foi reafirmada; a pesquisa da universidade pública brasileira tem assumido um protagonismo social e político nunca visto; e a criação de uma renda mínima foi articulada. Em comum, elas permitem conjeturar o lançamento de bases para a reformulação do lugar do público na sociedade brasileira.

Em sua acepção original, crise (krisis) correspondia à fase decisiva de uma doença em que o enfermo se recuperava ou padecia. É, pois, uma ruptura com o estado anterior das coisas. No caso de uma crise social, há uma peculiaridade: as alternativas a seguir dependem dos sujeitos. O "como" da pergunta anterior depende, portanto, de nós, a quem cabe encontrar diretrizes de ação. Nessa ruptura, os princípios democráticos e republicanos da carta constitucional que nos rege parecem ser um ótimo guia.

\section{ADENDO ESCRITO SEIS MESES DEPOIS, AINDA EM CONTEXTO PANDÊMICO}

A primeira versão do texto acima foi publicada, com ligeiras modificações, em abril de 2020. Passados seis meses, cabe fazer uma breve observação a respeito dos indícios mencionados no penúltimo parágrafo. Teriam eles demonstrado ser capazes de rearticular o lugar do "público" na vida social brasileira?

O desenlace do processo político e social no qual se inserem não está inteiramente claro, embora seja seguro afirmar que o aparato público de pesquisa e ensino superior nacional continuou a demonstrar sua relevância - assim indicam os papéis desempenhados por instituições como a Fundação Oswaldo Cruz (Fiocruz) e o Instituto Butantan, líderes no processo de pesquisa e produção da vacina. Outra questão - e aqui entramos no terreno das incertezas próprias à crítica situação política em que vivemos - é saber como tais insti- 
tuições serão tratadas pelo governo e pela sociedade brasileira no futuro. Se tomarmos como base a reação popular contra o decreto I0.530, pode-se imaginar, na linha do indicado em abril, que o SUS e instituições próximas ou pertencentes a ele sairão fortalecidos da pandemia em que vivemos.

Por outro lado, a questão referente à renda mínima parece ainda mais incerta. Ela não apenas foi estabelecida de modo temporário, como sua modalidade de aplicação - a ajuda emergencial -, embora importante para milhões de pessoas em situação de vulnerabilidade, ainda tem futuro nublado. O momento pós-eleitoral deverá ser crítico para o clareamento da sua evolução, uma vez que o contexto de disputa política incentiva os governantes a adiar decisões potencialmente impopulares.

Há também, pelo menos, dois episódios para os quais vale chamar a atenção a partir da perspectiva aqui adotada: o imbróglio envolvendo a adoção e a aplicação de vacinas contra a covid-ı 9 e a nova onda de disseminação do vírus em países que se supunha terem controlado sua circulação. Em ambos, os impasses da complexa situação política que vivemos se revelam.

Quanto ao primeiro aspecto, seria ingênuo, especialmente no contexto atual, imaginar que a situação se desenvolveria sem intensa "politização" - entendida, aqui, como situação em que os atores políticos se valem de determinados recursos para angariar popularidade a partir de uma circunstância propícia. O que chama a atenção não é o fato de que os dirigentes político-partidários procurem aumentar seus capitais políticos a partir das posições favoráveis, ou contrárias, à vacinação - a depender de seu eleitorado -, mas sim o grau a que chegou essa orientação ultrapragmática e ultraindividualista. Essa intensidade revela uma faceta conflitiva da relação entre política e direito, no caso, o direito à vida, conforme trecho citado da Constituição. É como se a esfera da política tivesse suplantado a do direito, supostamente delimitadora da primeira. Um dos riscos envolvidos nesse tipo de conflito é uma espécie de vale tudo político-eleitoral em que se arriscam as vidas de milhares de pessoas. A reação do âmbito jurídico é, conforme seus instrumentos específicos, “judicializar" a política, o que também estatui problemas para a democracia, uma vez que, entre os três poderes que constituem a organização do Estado, o menos aberto à influência popular é o que tem, em sua cúpula, o Supremo Tribunal Federal (STF). Nesse conflito entre política e direito, percebe-se uma espécie de maximização da perversão que assola a política em tempos de crise da democracia - o que tornaria possível, aliás, formular a hipótese de que o que está em jogo é mais do que uma crise de um regime político dominante no mundo, mas a própria lógica da política tal como a conhecemos. Apesar desse quadro profundamente estável, a Fiocruz estima iniciar sua produção da vacina em janeiro e fevereiro de 202 I (Brasil, 2020).

Quanto à segunda onda de contaminação do coronavírus na Europa, as informações ainda não estão claras. Há indicações de que a reabertura das 
atividades teve papel decisivo nessa nova explosão dos números de contaminados (em geral jovens), cuja taxa de mortalidade parece menor do que aquela do início da pandemia. Enquanto escrevo, Alemanha, Inglaterra e França estabeleceram novo lockdown, que pode perdurar até dezembro. A solução imediatamente disponível é a adoção das orientações dos órgãos competentes, liderados pela Organização Mundial da Saúde (OMS), entre as quais se destacam duas: ampliar a testagem e rastrear contatos (Biernath, 2020). O cumprimento dessas indicações pode ser facilitado pela experiência de tais países, adquirida durante a primeira onda. Por outro lado, porém, no plano sociopolítico, pode ser que assistamos ao aumento de pressões para repactuações sociais em alguns países, possivelmente ligadas ao fato de que novos fechamentos e bloqueios econômicos devem agravar a vulnerabilidade social de setores já precarizados (Villadarga, 2020). Discussões sobre renda mínima e outras medidas sociais podem voltar a ganhar espaço no exterior, talvez influenciadas por resultados moderadamente positivos da experiência finlandesa (Wallin, 2020).

Não sabemos quais serão os efeitos dessa segunda onda por aqui. É certo, porém, que não há como as medidas preventivas citadas serem aplicadas adequadamente no país sem investimentos em seu aparato público de saúde e pesquisa. Investimentos republicanos e democráticos.

Recebido em 02/I I/2020 | Aprovado em 06/I I/202 I

Leonardo Octavio Belinelli de Brito é doutor em ciência política pela Universidade de São Paulo, onde faz estágio-pós-doutoral com bolsa do CNPq. Pesquisa nas áreas de pensamento político e social brasileiro e teoria política. É autor de Dilemas do patrimonialismo brasileiro: as interpretações de Raymundo Faoro e Simon Schwartzman e coautor de Estado e democracia: uma introdução ao estudo da política. 


\section{NOTA}

I Para um breve panorama de algumas, entre as muitas, intervenções bem-vindas dos cientistas sociais na conjuntura atual, vejam-se os boletins "Cientistas sociais e o coronavírus" divulgados pela Associação Nacional de Pesquisa e Pós-Graduação em Ciências Sociais (Anpocs) em parceria com a Sociedade Brasileira de Sociologia (SBS), a Associação Brasileira de Antropologia (ABA) e a Associação Brasileira de Ciência Política (ABCP).

\section{REFERÊNCIAS}

Biernath, André. (2020). Covid-ı9: as lições que Brasil pode aprender com a segunda onda de casos na Europa. BBC, 28 de outubro de 2020. Disponível em: https://www.bbc.com/ portuguese/brasil-547I4682. Acesso em 3I out. 2020.

Botelho, André; Ricupero, Bernardo; Brasil Jr., Antônio. (2017). Cosmopolitism and localism in the Brazilian social sciences. Canadian Review of Sociology - Revue Canadienne de Sociologie, 54, p. 216-236.

Brandão, Gildo Marçal. (2007). Linhagens do pensamento político brasileiro. São Paulo: Hucitec.

Brasil, Cristina. (2020). Fiocruz espera que vacinação contra covid-Ig comece até março de 202I. Agência Brasil, 02 nov. 2020. Disponível em: https://agenciabrasil.ebc.com.br/saude/ noticia/2020-II/fiocruz-espera-que-vacinacao-contra-covid-I9-comece-ate-marco-de-202I. Acesso em 28 maio $202 \mathrm{I}$. Carvalho, José Murilo de Carvalho. (20I6). A cidadania no Brasil: o longo caminho. Rio de Janeiro: Civilização Brasileira.

Fernandes, Florestan. (I97I). A análise sociológica das classes sociais. In: Ensaios de sociologia geral e aplicada. São Paulo: Livraria Pioneira.

Perissé, André Reynaldo Santos. (2020). O papel do SUS em contexto de crise. Boletim Lua Nova. Disponível em: https:// boletimluanova.org/2020/o4/or/o-papel-do-sus- em-contexto-de-crise/\#: : text=Desde\% 20 sua\% 2 oimplementa\% $\mathrm{C}_{3} \% \mathrm{~A}_{7} \% \mathrm{C}_{3} \% \mathrm{~A}_{3} 0 \% 2 \mathrm{C} \% 200 \% 20$ sub,ap\%C3\%B35\%20a\%20Emenda\%20Constitucional\% 2095.\&text $=\mathrm{Na} \% 20$ sa\%C3\%BAde $\% 2 \mathrm{C} \%$ 2 opor\%C3\%Agm\%2C\%200\% 20impacto,para\%200\%20atendimento $\% 20$ no $\% 20$ SUS. Acesso em 20 out. 2020. 
Schwarcz, Lilia; Starling, Heloísa M. (orgs.). (2019). Dicionário da República: 5 I textos críticos. São Paulo: Companhia das Letras.

Villadarga, Vicente. (2020). Uma segunda onda ainda mais letal. IstoÉ, 30 de outubro de 2020. Disponível em: https:// istoe.com.br/uma-segunda-onda-ainda-mais-letal/. Acesso em 30 out. 2020 .

Wallin, Claudia. (2020). Finlândia: estudo final sobre renda mínima revela pouca melhora no nível de emprego e mais qualidade de vida. RFI, 06 de maio de 2020. Disponível em: https://www.rfi.fr/br/europa/20200506-finl\%C3\%A2ndiaestudo-final-sobre-renda-m\%C3\%ADnima-revela-poucamelhora-no-n\%C3\%ADvel-de-emprego-e-mais-qualidadede-vida. Acesso em 02 nov. 2020. 


\section{REPÚBLICA, DEMOCRACIA E CIDADANIA EM TEMPOS DE PANDEMIA: UMA NOTA SOBRE A SITUAÇÃO BRASILEIRA \\ Resumo}

O artigo discute a relação entre república, democracia e cidadania no Brasil no contexto da pandemia global da covid-I9. Argumenta que as desigualdades sociais podem ser agravadas com a expansão do raio de ação do vírus, ao mesmo tempo em que assinala algumas brechas que podem ser ponto de partida para a superação do quadro. Tais possibilidades se vinculam ao fortalecimento dos ideais republicanos e democráticos.

\section{REPUBLIC, DEMOCRACY AND CITIZENSHIP IN} PANDEMIC TIMES: A NOTE ON THE

BRAZILIAN SITUATION

Abstract

The article discusses the relationship between republic, democracy and citizenship in Brazil in the context of the covid-I 9 global pandemic. It argues that social inequalities can be aggravated with the expansion of the virus's range of action, while some gaps are pointed out that can be a starting point for overcoming the situation. Such possibilities are linked to the strengthening of republican and democratic ideals.
Palavras-chave

República;

democracia;

cidadania;

Brasil;

pandemia.

\section{Keywords}

Republic;

democracy; citizenship;

Brazil;

pandemic. 